\title{
Оценка возможности применения SRAP-маркеров для ДНК- идентификации российских сортов люцерны
}

Мавлютов Ю.М.*, м.н.с. аспирант; Шамустакимова А.О., н.с.; Клименко И.А., к.с.-х.н., с.н.с. ФНЦ «ВИК им. В.Р. Вильямса», г. Лобня, Россия *e-mail: yulian92@mail.ru

Изучалась возможность использования SRAP-маркеров для идентификации сортов лючерны отечественной селекции. Результаты исследований показали, что данная маркерная техника пригодна для выявления межсортовых различий на генетическом уровне.

Ключевые слова: геном, люиерна, SRAP-маркеры, полиморфизм ДНК, генетическое разнообразие.

\section{Estimation of the possibility to use SRAP-markers for DNA-identification of Russian alfalfa cultivars}

Mavlyutov Y.M.*, Shamustakimova A.O., Klimenko I. A.

Federal Williams Research Center of Forage Production \& Agroecology, Lobnya, Russia.*e-mail: yulian92@mail.ru

The results of using SRAP-markers for identification of Russian alfalfa cultivars are presented in this study. It was found that this marker system is suitable for evaluation the differences between the analyzed cultivars.

Key words: genome, alfalfa, SRAP-markers, DNA-polymorphism, genetic diversity.

Люцерна является ценной кормовой культурой, широко используемой в качестве источника дешевого растительного белка и энергии для всех видов скота и птицы. Ее применяют в виде зеленого корма, как сырье для приготовления силоса, сенажа и травяной муки [1], включают в состав травосмесей с целью обогащения почвы биологическим азотом и активации микробиологических процессов. Биологические и хозяйственно-ценные особенности этой культуры обусловили создание системы современных сортов, обладающих высокой продуктивностью, долголетием, устойчивостью к болезням и вредителям [2].

До настоящего времени российские сорта люцерны различают только по морфологическим признакам. Выгодно отличаются от классических подходов методы ДНК-идентификации. Они не требуют фенотипического проявления признака, могут применяться на любой стадии развития растений и существенно сокращают затраты труда и времени на выявление межвидовых 
и межсортовых различий. Для оценки генетического разнообразия используют различные молекулярные маркерные системы, каждая из которых имеет свои преимущества и недостатки [3]. Простым и эффективным является метод, основанный на использовании SRAP-маркеров (Sequence-related amplified polymorphism) для амплификации интрон-экзонных областей генома, или открытых рамок считывания (Open reading Frame, ORF) исследуемых организмов. Вариабельность продуктов ПЦР достигается за счет обратного праймера, нацеленного на некодирующую область генома, обладающую низкой консервативностью. Использование SRAP-маркеров при оценке генетического разнообразия позволяет получить надежные и воспроизводимые результаты [4, 5].

Целью нашего исследования являлась оценка SRAP-маркерной системы, как инструмента для выявления различий между сортами люцерны отечественной селекции.

Материалы, методы и условия проведения исследований. Объектом исследования служили 18 сортов и образцов люцерны, относящиеся к разным видам (табл. 1).

Таблица 1 - Перечень исследуемых сортов люцерны

\begin{tabular}{|c|l|l|}
\hline №№ & \multicolumn{1}{|c|}{ Наименование сорта } & \multicolumn{1}{c|}{ Вид } \\
\hline 1 & Луговая 67 & Medicago varia Mart. \\
\hline 2 & Вега 87 & Medicago varia Mart. \\
\hline 3 & Лада & Medicago varia Mart. \\
\hline 4 & Агния & Medicago varia Mart. \\
\hline 5 & Тамбовчанка & Medicago sativa L. \\
\hline 6 & Камелия & Medicago varia Mart. \\
\hline 7 & Воронежская & Medicago varia Mart. \\
\hline 8 & Влада & Medicago varia Mart. \\
\hline 9 & Селена & Medicago varia Mart. \\
\hline 10 & Таисия & Medicago varia Mart. \\
\hline 11 & Мира & Medicago lupulina L. \\
\hline 12 & Вела & Medicago varia Mart. \\
\hline 13 & Сарга & Medicago varia Mart. \\
\hline 14 & Пастбищная 88 & Medicago varia Mart. \\
\hline 15 & Сортообразец А2 & Medicago varia Mart. \\
\hline 16 & Узень & Medicago sativa L. \\
\hline 17 & Находка & Medicago varia Mart. \\
\hline 18 & Благодать & Medicago varia Mart. \\
\hline
\end{tabular}

Для выделения ДНК использовали 7-дневные проростки и коммерческий набор реагентов «ДНК-ЭКСТРАН-3» от компании «Синтол» (Россия).

Реакционная смесь объемом 25 мкл содержала 10x Taq Turbo buffer, 50x dNTP mix, 2U Taq-ДНК полимеразы, а также по 0,2 мкМ каждого праймера и 20 нг ДНК. Амплификация проходила на приборе «Bio-Rad iCycler, 
USA» в соответствии с условиями, предложенными Li и Quiros [4] с внесением некоторых модификаций. Детекция результатов ПЦР проводилась путем электрофореза в 1,6 \% агарозном геле. Для оценки размера продуктов амплификации использовали молекулярный маркер $1 \mathrm{~kb}$ DNA Ladder («Евроген», Россия).

Результаты и обсуждение. Для генотипирования 18 сортов и образцов люцерны использовали 25 комбинаций из одиночных SRAP-праймеров (табл. 2), синтез которых осуществлен в компании «Евроген» на основе информации, полученной из источников литературы [6].

Таблица 2 - Нуклеотидные последовательности SRAP - праймеров, использованных для выявления полиморфных локусов

\begin{tabular}{|c|c|c|c|}
\hline $\begin{array}{c}\text { Прямые } \\
\text { праймеры } \\
(\mathrm{F})\end{array}$ & $\begin{array}{c}\text { Последовательность } \\
\left(5^{\prime} \rightarrow 3^{\prime}\right)\end{array}$ & $\begin{array}{c}\text { Обратные } \\
\text { праймеры } \\
(\mathrm{R})\end{array}$ & $\begin{array}{c}\text { Последовательность } \\
\left(5^{\prime} \rightarrow 3^{\prime}\right)\end{array}$ \\
\hline F9 & GTAGCACAAGCCGGACC & R9 & GACTGCGTACGAATTTCA \\
\hline F13 & CGAATCTTAGCCGGCAC & R7 & GACTGCGTACGAATTGAG \\
\hline Me4 & CGAATCTTAGCCGGAAT & Em2 & GACTGCGTACGAATTCGG \\
\hline F10 & GTAGCACAAGCCGGAAG & R14 & CGCACGTCCGTAATTAAC \\
\hline F11 & CGAATCTTAGCCGGATA & R8 & GACACCGTACGAATTGAC \\
\hline
\end{tabular}

По результатам ПЦР-анализа отобраны 7 информативных комбинаций, позволяющих выявить ДНК-полиморфизм исследуемых сортов (табл. 3).

Таблица 3 - Результаты оценки ДНК-полиморфизма сортов люцерны с использованием SRAP-маркеров

\begin{tabular}{|c|c|c|c|c|}
\hline $\begin{array}{c}\text { Комбина- } \\
\text { ция прай- } \\
\text { меров }\end{array}$ & $\begin{array}{c}\text { Общее коли- } \\
\text { чество ПЦР- } \\
\text { продуктов }\end{array}$ & $\begin{array}{c}\text { Размер ПЦР- } \\
\text { продуктов, п. н. }\end{array}$ & $\begin{array}{c}\text { Количество по- } \\
\text { пиморфных } \\
\text { ПЦР-продуктов }\end{array}$ & $\begin{array}{c}\% \\
\text { полиморфизма }\end{array}$ \\
\hline F9-R9 & 25 & $105-490$ & 7 & 28 \\
\hline F9-R8 & 14 & $125-385$ & 3 & 21 \\
\hline F13-Em2 & 9 & $125-235$ & 3 & 33 \\
\hline F10-R7 & 16 & $165-708$ & 6 & 38 \\
\hline F10-R8 & 27 & $145-708$ & 8 & 30 \\
\hline F13-R9 & 20 & $60-485$ & 5 & 25 \\
\hline F13-R7 & 18 & $50-305$ & 9 & 50 \\
\hline
\end{tabular}

С использованием информативных SRAP-праймеров удалось выявить 129 ПЦР-продуктов, из которых 41 оказался полиморфным. При этом длина ПЦР-продуктов варьировала от 50 до 708 пар нуклеотидов.

Сорт Мира (Medicago lupulina L.) выделялся среди других образцов наличием уникальных фрагментов амплификации со всеми испытанными комбинациями праймеров. В качестве примера на рисунке представлена электрофореграмма ПЦР-продуктов, полученных с использованием прай- 
мерной пары F10-R7 (белой стрелкой обозначен ампликон 275 п.н., отличающий его от остальных сортов). С этой же комбинацией праймеров обнаружен специфический ампликон для сорта Селена в 316 п.н. (обозначен черной стрелкой).

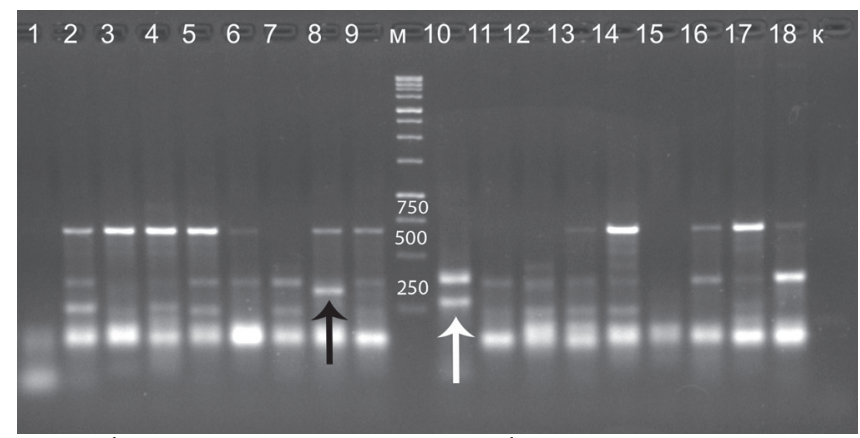

Рисунок. Электрофореграмма продуктов амплификации ДНК сортов люцерны с комбинацией SRAP-праймеров F10-R7, где лунки 1-18 сорта: Вега 87, Лада, Агния, Тамбовчанка, Камелия, Воронежская, Влада, Селена, Таисия, Мира, Вела, Сарга, Пастбищная 88, сортообразец А2, Луговая 67, Узень, Находка, Благодать, к - контроль $\left(\mathrm{H}_{2} \mathrm{O}\right)$, м - маркер молекулярного веса $1 \mathrm{~kb}$ DNA Ladder.

По результатам проведенного исследования можно сделать вывод о пригодности ПЦР-техники на основе SRAP-маркеров для оценки различий между российскими сортами и видами люцерны. Способность SRAPмаркеров амплифицировать кодирующие последовательности в геноме открывает возможности для идентификации локусов, связанных с хозяйственно-ценными признаками [4].

\section{Список литературь}

1. Писковацкий Ю.М. и др. Агротехника возделывания сортов люцерны селекции ВНИИ кормов им. ВР Вильямса на семенные и кормовые цели. - 2008. - С. 3-15.

2. Косолапов В.М. и др. Актуальные направления селекции и использование люцерны в кормопроизводстве. - 2014. - С. 4-6.

3. Хлесткина Е.К. Молекулярные маркеры в генетических исследованиях и в селекции // Вавиловский журнал генетики и селекции. - 2015. - Т. 17. - №. 4/2. - С. 1044-1054.

4. Li G., Quiros C.F. Sequence-related amplified polymorphism (SRAP), a new marker system based on a simple PCR reaction: its application to mapping and gene tagging in Brassica // Theoretical and applied genetics. - 2001. - T. 103. - №. 2-3. - C. 455-461.

5. Robarts D.W.H., Wolfe A.D. Sequence-related amplified polymorphism (SRAP) markers: A potential resource for studies in plant molecular biology1//Applications in plant sciences. - 2014. - T. 2. - №. 7. - C. 1400017.

6. Rhouma H.B. et al. Assessment of the genetic variation in alfalfa genotypes using SRAP markers for breeding purposes // Chilean journal of agricultural research. - 2017. T. 77. - №. 4. - C. 332-339. 